\title{
Optimasi desain dan analisis kekuatan struktur sayap komposit dengan variasi material, thickness, arah serat dan kondisi batas menggunakan MSC Patran Nastran (studi kasus pesawat UAV CH-4)
}

\author{
Muhammad Ervin Adamy*, Muhammad Abdul Ghofur, Ardian Infantono, \\ Yustina Titin Purwantiningsih
}

Prodi Teknik Aeronautika Pertahanan, Akademi Angkatan Udara, Yogyakarta, Indonesia

Email Korespondensi : *ervinadamy@gmail.com

\begin{abstract}
Abstrak. Struktur pada pesawat terbang berfungsi untuk mentransfer beban-beban yang terjadi pada permukaan pesawat ke bidang lain yang memiliki kekuatan lebih besar sehingga komponen pesawat tidak mengalami kegagalan karena setiap komponen menerima beban yang relatif kecil. Pada perancangan struktur sayap pesawat terbang, hal paling utama yang harus diperhatikan adalah masalah berat dan kekuatan struktur. Struktur yang dibuat harus memiliki kekuatan maksimal dengan berat seringan mungkin serta memenuhi faktor keamanan (safety factor). Penelitian ini melakukan desain optimasi dan analisis kekuatan stuktur sayap pesawat dengan memvariasikan jenis material, thickness dan kondisi batas. Jenis material yang diaplikasikan dalam penelitian ini adalah komposit carbon/epoxy T300/N5208, Alumunium dan Titanium. Material komposit dengan berbagai varisasi susunan arah serat dimana lamina disusun secara simetris dengan arah serat $\left(90^{\circ} / 90^{\circ} / 90^{\circ} / 90^{\circ}\right) \mathrm{s},\left(45^{\circ} / 45^{\circ} / 45^{\circ} / 45^{\circ}\right) \mathrm{s},\left(0^{\circ} / 0^{\circ} / 0^{\circ} / 0^{\circ}\right) \mathrm{s},\left(0^{\circ} / 0^{\circ} / 90^{\circ} / 90^{\circ}\right) \mathrm{s}$ dan $\left(0^{\circ} / 45^{\circ} / 45^{\circ} / 90^{\circ}\right) \mathrm{s}$ dan ketebalan per layer nya sebesar $0,000125 \mathrm{~m}$ atau $0,125 \mathrm{~mm}$. Thickness dibuat seragam dari wingroot sampai dengan wingtip, kemudian thickness dibuat bervariasi dengan membagi tiga section sayap. Kondisi batas diposisikan di ujung spar dan diposisikan di bagian ujung skin sayap. Desain optimasi dan analisis kekuatan struktur Ribs, Spar dan Skin menggunakan Patran Nastran. Objek penelitian ini pada perancangan geometri sayap mengambil studi kasus pada jenis pesawat UAV CH4 Rainbow milik TNI AU. Dalam penelitian ini diperoleh stress dan weight pada ketebalan yang seragam dan posisi kondisi batas di spar untuk material komposit sebesar 75,8 MPa, 2,228 x $103 \mathrm{Kg}$. Material alumunium sebesar 59,2 MPa, 3,871 x 103 dan material titanium sebesar 59,2 MPa, 6,168 x 107 . Desain optimasi dilakukan dalam penelitian ini dengan cara memvariasikan ketebalan dan menambah posisi kondisi batas di ujung skin sayap, diperoleh stress, defleksi dan weight untuk material komposit sebesar $551 \mathrm{MPa}, 0,675 \mathrm{~m}, 277 \mathrm{Kg}$. Material alumunium memperoleh stress dan weight sebesar 59,2 MPa, $3871 \mathrm{Kg}$ dan material titanium sebesar 59,2 MPa, $6168 \mathrm{Kg}$. Dengan demikian, desain struktur sayap pesawat UAV CH-4 Rainbow yang paling optimal adalah komposit dengan variasi ketebalan spar dan rib $(1 \mathrm{~cm}, 0,75 \mathrm{~cm}, 0,5 \mathrm{~cm})$ serta skin $(0,375 \mathrm{~cm}, 0,25 \mathrm{~cm}, 0,125 \mathrm{~cm})$.
\end{abstract}

Kata Kunci: Sayap, Komposit, Alumunium, Titanium, Stress, Defleksi, Weight, Patran Nastran. 


\section{Pendahuluan}

Desain pesawat mempertimbangkan banyak faktor seperti keselamatan, efisiensi, keandalan, dan kenyamanan. Namun, pentingnya semua aspek ini tergantung pada jenis pesawat yang dirancang dapat bervariasi dari mulai pesawat tempur, pesawat komersial sampai pesawat UAV. Akibatnya, desain pesawat harus memenuhi persyaratan yang berpengaruh pada material yang digunakan dalam konstruksinya dan kompleksitas strukturnya. Banyak jenis material yang dapat digunakan dalam desain pesawat untuk mendapatkan sifat yang baik tersebut sebagai, elastisitas, kekuatan dan berat, Juga dapat digunakan bahan yang berbeda dalam desain bagian-bagian pesawat, sebagai fungsi dari kebutuhan awal dari strength to weight ratio dan arah preferensial dari beban yang diterapkan [1]. Struktur pada pesawat terbang berfungsi untuk mentransfer beban yang terjadi pada permukaan pesawat ke bidang lain yang memiliki kekuatan lebih besar sehingga komponen pesawat tidak mengalami kegagalan karena setiap komponen menerima beban yang relatif kecil. Pada perancangan struktur sayap pesawat terbang, hal paling utama yang harus diperhatikan adalah masalah berat dan kekuatan struktur. Struktur yang dibuat harus memiliki kekuatan maksimal dengan berat seringan mungkin serta memenuhi faktor keamanan (safety factor). Dari awal diciptakanya pesawat terbang berbahan kayu, aluminium, titanium kemudian hingga digunakanya komposit. Dengan penerapan material komposit, berat struktur pesawat bisa berkurang sekitar 25\% 30\% dibandingkan dengan konvensional struktur logam [2]. Penerapan material komposit dengan weight yang ringan dan kekuatan yang tinggi tidak hanya sekedar mengurangi weight struktur nya saja, tetapi juga mampu mendapatkan nilai elastisitas dari komposit untuk mewujudkan bending dan torsi yang kompleks pada deformasi sayap yang tentunya untuk memenuhi persyaratan stiffness and strength struktur komposit [3]. Struktur sayap pesawat yang paling ringan dalam perancangan sayap pesawat komposit aspek rasio tinggi adalah dengan menggunakan material komposit orthotropik $\left(0^{\circ} / 0^{\circ} / 45^{\circ} / 45^{\circ}\right)$ s, sehingga ini menunjukkan bahwa material komposit mampu menjadi solusi terhadap permasalahan yang spesifik pada perancangan sayap yang memiliki aspek rasio tinggi. Konfigurasi laminasi $\left(0 \% 0 \%+45^{\circ} \%-45^{\circ}\right) \mathrm{s} 30 \%$ lebih ringan daripada yang memiliki konfigurasi kuasiisotropik, dan $60 \%$ lebih ringan dari pada sayap aluminium [4]. Struktur sayap dengan ketebalan yang sama, variasinya pada orientasi serat akan menghasilkan variasi von Mises stres dan perpindahan (naik atau turun) [5]. Penggunaan material komposit terus dikembangkan pada struktur pesawat terbang. Dalam penelitian ini dilaksanakan optimasi desain dan analisis kekuatan struktur sayap Komposit, Alumunium dan Titanium (studi kasus pada pesawat UAV CH-4) dengan variasi material, thickness, arah serat dan kondisi batas menggunakan MSC Patran Nastran. Jenis material yang diaplikasikan dalam penelitian ini adalah komposit carbon/epoxy T300/N5208, Alumunium dan Titanium. Thickness dibuat seragam dari wingroot sampai dengan wingtip, dan dibuat bervariasi dengan membagi tiga section sayap. Arah serat diujikan dengan variasi sudut $\left(90^{\circ} / 90^{\circ} / 90^{\circ} / 90^{\circ}\right) \mathrm{s},\left(45^{\circ} / 45^{\circ} / 45^{\circ} / 45^{\circ}\right) \mathrm{s},\left(0^{\circ} / 0^{\circ} / 0^{\circ} / 0^{\circ}\right) \mathrm{s},\left(0^{\circ} / 0^{\circ} / 90^{\circ} / 90^{\circ}\right) \mathrm{s}$ dan $\left(0^{\circ} / 45^{\circ} / 45^{\circ} / 90^{\circ}\right) \mathrm{s}$. Kondisi batas diposisikan di bagian ujung spar dan diposisikan di bagian ujung skin sayap. Desain optimasi dan analisis kekuatan struktur sayap ini menggunakan MSC Patran Nastran.

\section{Metode Penelitian}

Penelitian ini melakukan desain optimasi dan analisis kekuatan stuktur sayap pesawat dengan memvariasikan jenis material, thickness dan kondisi batas. Jenis material yang diaplikasikan dalam penelitian ini adalah komposit carbon/epoxy T300/N5208 (Tabel 1), Alumunium dan Titanium. Material komposit dengan berbagai varisasi susunan arah serat dimana lamina disusun secara simetris dengan arah serat $\left(90^{\circ} / 90^{\circ} / 90^{\circ} / 90^{\circ}\right) \mathrm{s},\left(45^{\circ} / 45^{\circ} / 45^{\circ} / 45^{\circ}\right) \mathrm{s},\left(0^{\circ} / 0^{\circ} / 0^{\circ} / 0^{\circ}\right) \mathrm{s},\left(0^{\circ} / 0^{\circ} / 90^{\circ} / 90^{\circ}\right) \mathrm{s}$ dan $\left(0^{\circ} / 45^{\circ} / 45^{\circ} / 90^{\circ}\right) \mathrm{s}$ dan ketebalan per layer nya sebesar $0,000125 \mathrm{~m}$ atau $0,125 \mathrm{~mm}$. Thickness dibuat seragam dari wingroot sampai dengan wingtip, kemudian thickness dibuat bervariasi dengan membagi tiga section sayap. Kondisi batas diposisikan di ujung spar dan diposisikan di bagian ujung skin sayap. Desain optimasi dan analisis kekuatan struktur Ribs, Spar dan Skin menggunakan Patran Nastran. Objek penelitian ini pada perancangan geometri sayap mengambil studi kasus pada jenis pesawat UAV CH4 Rainbow milik TNI AU (gambar 1).

Komposit merupakan gabungan antara bahan matriks atau pengikat dengan penguat. Dari penggabungan tersebut akan menghasilkan material komposit yang mempunyai sifat mekanis dan karakteristik yang berbeda dari material pembentuknya, sehingga dapat dibuat suatu komposit dengan kekuatan yang diinginkan. Lamina diartikan sebagai pelat atau lembar material komposit yang hanya mempunyai satu arah orientasi serat. Laminat adalah gabungan dua atau lebih lamina yang disusun bertumpuk yang 
masing-masing dipasang dengan sudut yang bervariasi. Laminat ini dibuat agar elemen dalam struktur tersebut mampu menahan beban multiaksial yang terjadi pada struktur, dimana hal ini tidak dapat dicapai oleh lapisan tunggal. Lapisan tunggal hanya kuat menahan beban pada arah seratnya, namun sangat lemah untuk arah tegak lurus seratnya. Sehingga agar mampu menahan beban multiaksial, lapisan harus digabung dengan lapisan lain dengan arah lapisan yang berbeda dengan lapisan lain.

Suatu struktur dikatakan gagal bila struktur tersebut tidak dapat lagi berfungsi dengan baik. Untuk menentukan apakah suatu lamina akan mengalami kegagalan atau tidak, digunakan kriteria kegagalan Tsai-Wu. Perancangan ini, terdapat langkah membandingkan beban yang terjadi dengan beban yang diijinkan. Perbandingan tersebut perlu supaya struktur mampu menahan beban yang terjadi dan tidak gagal. Kriteria kegagalan Tsai-Wu menyatakan bahwa material dari struktur komposit akan gagal bila perbandingan antara tegangan yang bekerja dengan kekuatan material yang dimiliki melebihi 1 (Failure Indices $>1$ atau FI > 1). Sedangkan penentuan Margin Safety untuk struktur sayap yang menggunakan bahan Alumunium dan Titanium adalah sebagai berikut:

$$
\text { Margin Safety }=\frac{\text { Yield Strength }}{\text { Ultimated Load }}-1
$$

Bila nilai Margin Safety lebih besar dari 0, maka struktur dinyatakan aman. Sedangkan bila lebih kecil dari 0 , maka struktur dinyatakan gagal.

Tabel 1. Material Carbon Epoxy T300 N5208

\begin{tabular}{lcc}
\hline \multicolumn{1}{c}{ Properties } & T300/N5208 & Satuan \\
\hline Volume fiber & $70 \%$ & \\
\hline Elastis Modulus 11 & $1,81 \mathrm{E} 11$ & $\mathrm{~Pa}$ \\
\hline Elastis & $1,03 \mathrm{E} 10$ & $\mathrm{~Pa}$ \\
\hline Poissin Ratio 12 & 0,28 & \\
\hline Shear Modulus 12 & $7,17 \mathrm{E} 9$ & $\mathrm{~Pa}$ \\
\hline Shear Modulus 23 & $5 \mathrm{E} 9$ & $\mathrm{~Pa}$ \\
\hline Shear Modulus 13 & $7,17 \mathrm{E} 9$ & $\mathrm{~Pa}$ \\
\hline Density & 1600 & $\mathrm{Kg} / \mathrm{m} 3$ \\
\hline Thermal Expan Coeff 11 & $2 \mathrm{E}-8$ & \\
\hline Thermal Expan Coeff 22 & $2,25 \mathrm{E}-5$ & \\
\hline Reference Temperature & 20 & \\
\hline
\end{tabular}




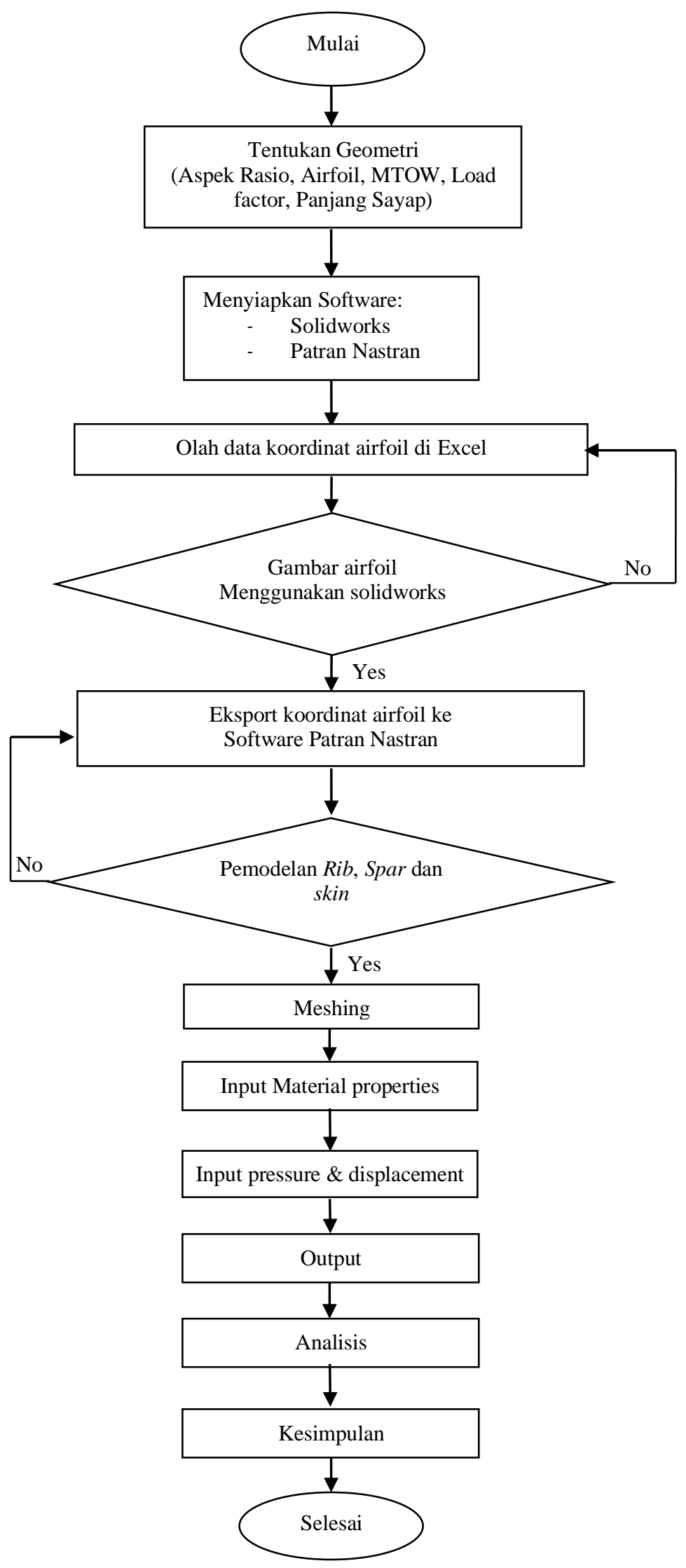

Gambar 1 Alur dalam penelitian 


\section{Hasil dan Analisis}

Pada penelitian ini, beban yang dihitung hanyalah beban akibat gaya angkat sedangkan gaya hambat dan momen aerodinamika diabaikan. Berikut ini adalah data pesawat :

Luas wing box bagian bawah $=5,240808 \mathrm{~m}^{2}$

MTOW $=1260 \mathrm{Kg}$

Load factor $=3$

Estimasi beban yang diterima oleh sayap utuh dapat dihitung menjadi:

$$
\begin{aligned}
& \text { Lift }=\text { MTOW } \times \text { g x Load factor } \\
& \text { Lift }=1260 \mathrm{Kg} \times 9.8 \mathrm{~m} / \mathrm{s}^{2} \times 3=37044 \mathrm{~N}
\end{aligned}
$$

Dengan demikian, maka satu sayap akan mendapat gaya sebesar 37044/2 $=18522$ N. Analisis sayap dibatasi hanya untuk analisis wing box sayap. Besarnya tekanan diperoleh dengan membagi beban yang telah dihitung tersebut dengan luas area wing box, yaitu sebesar 5,240808 $\mathrm{m}^{2}$. Besarnya tekanan yang diperoleh sebesar $18522 \mathrm{~N} / 5,240808 \mathrm{~m}^{2}=3534,187858 \mathrm{~Pa}$. Dengan safety factor 1,5 maka pressure menjadi 5301,3 $\mathrm{Pa}$ (gambar 2).

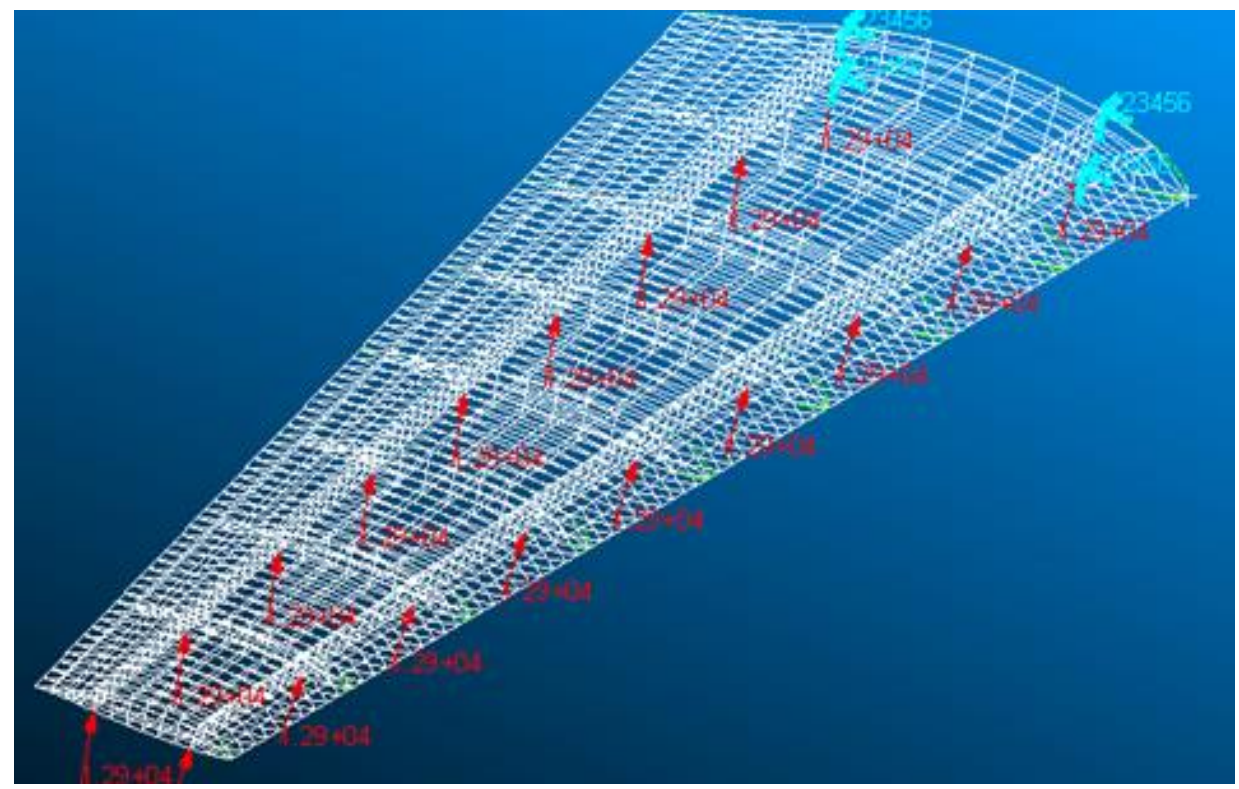

Gambar 2 Pemberian beban pada sayap

Rancangan sayap komposit yang menggunakan arah fiber $\left(0^{\circ}\right)$ mampu menahan stress maksimal sebesar 97,8 MPa dan defleksi sebesar 0,0296 m (gambar 3 dan 4).

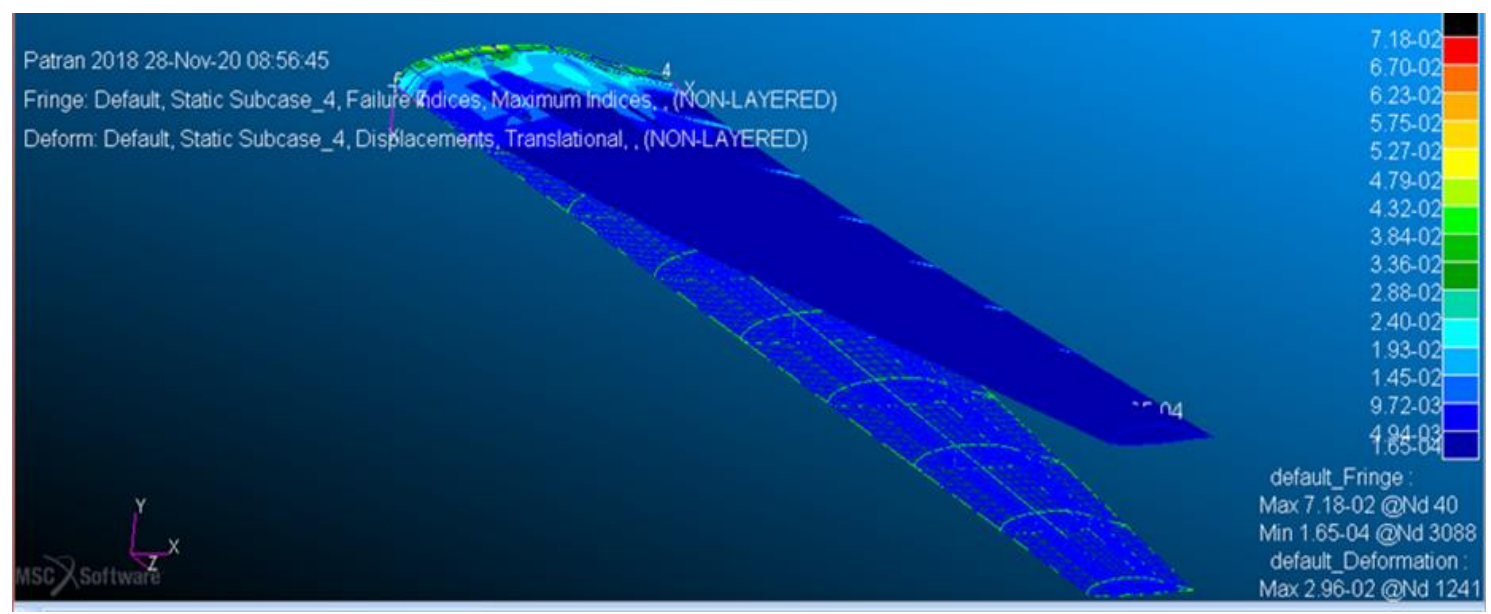

Gambar 3 Hasil Failure Indices dan deformasi komposit $0^{\circ}$ 


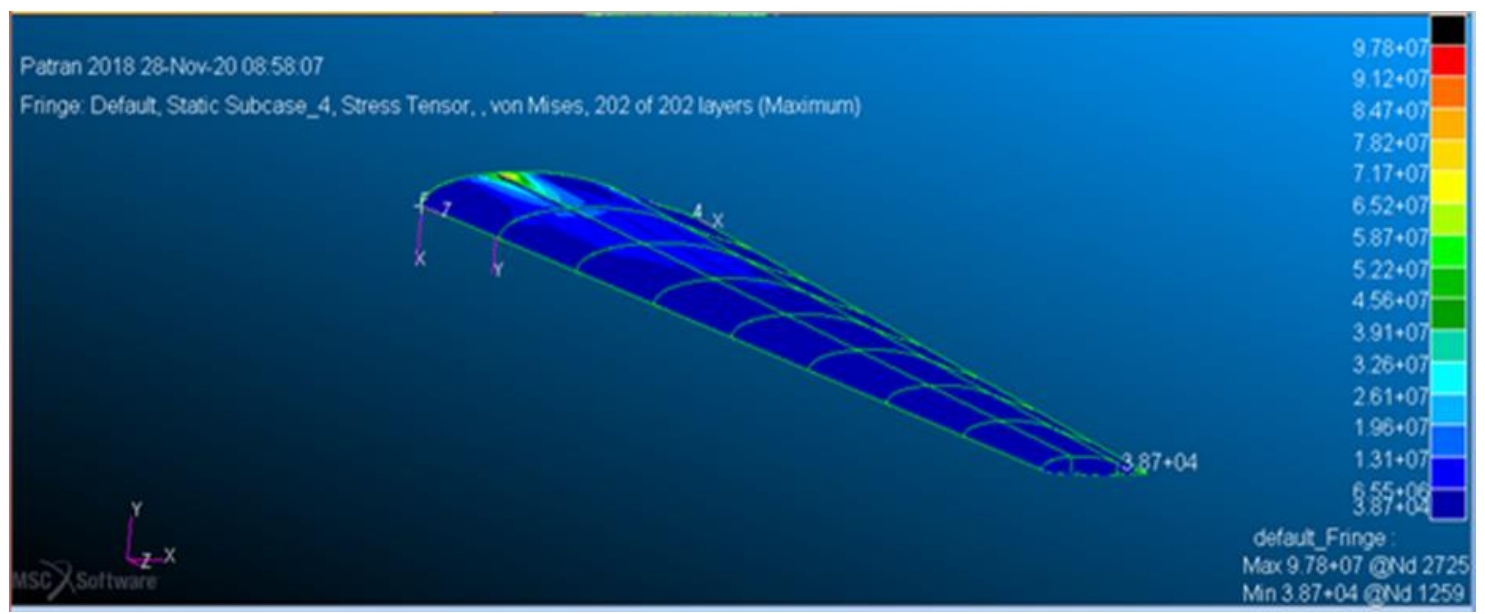

Gambar 4 Hasil stress komposit arah serat $0^{\circ}$

Rancangan sayap komposit yang menggunakan arah fiber $\left(45^{\circ}\right)$ mampu menahan stress maksimal sebesar 69,6 MPa dan defleksi sebesar 0,152 m (gambar 5 dan 6).

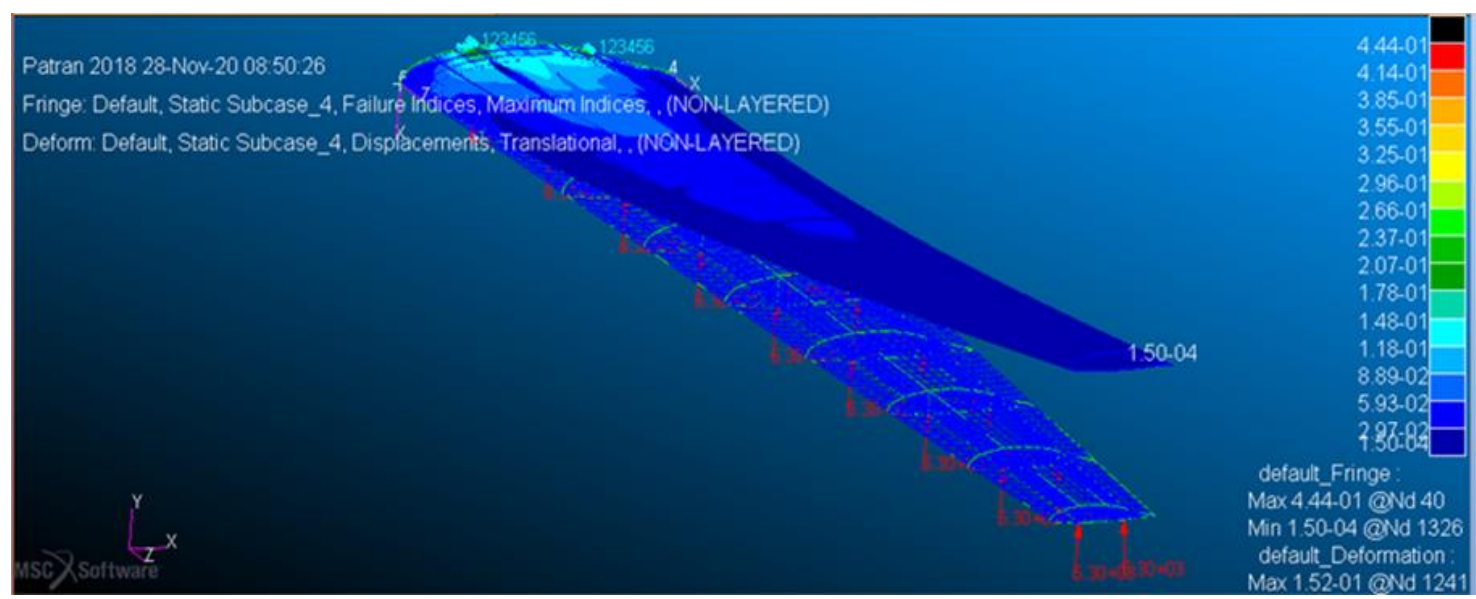

Gambar 5 Hasil Failure Indices dan deformasi komposit arah serat $45^{\circ}$

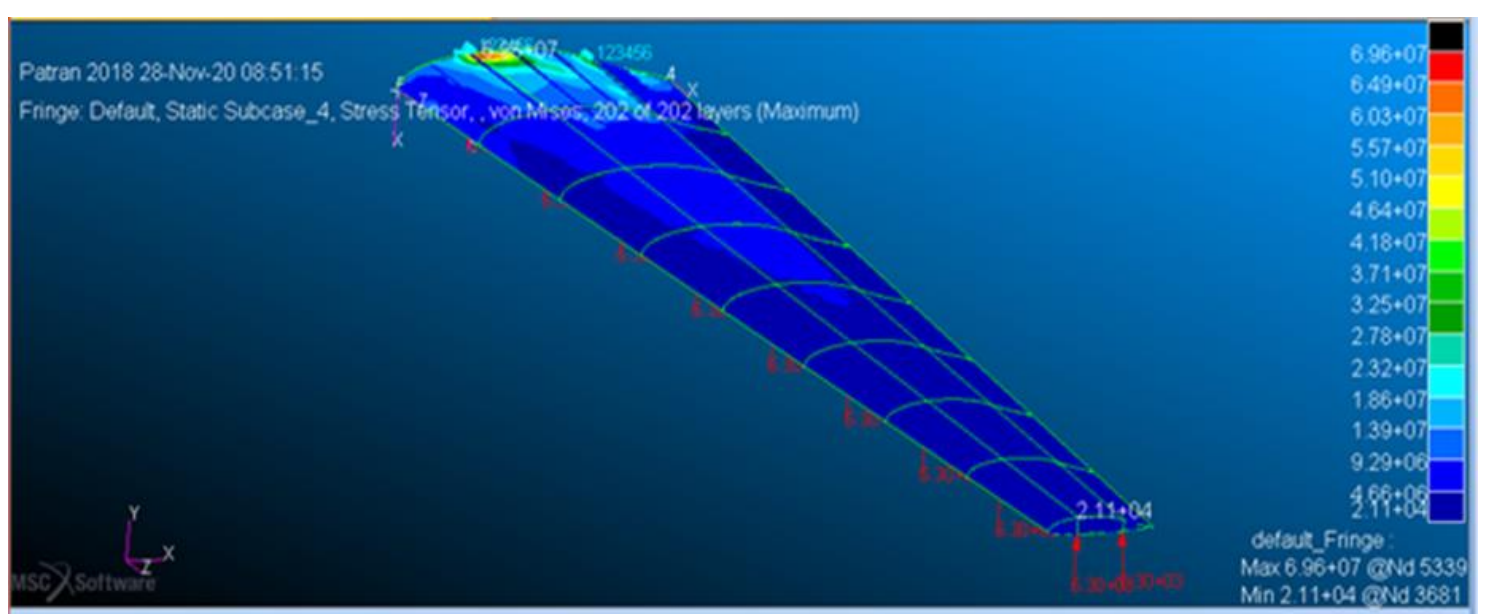

Gambar 6 Hasil stress material komposit arah serat $45^{\circ}$

Rancangan sayap komposit yang menggunakan arah fiber $\left(90^{\circ}\right)$ mampu menahan stress maksimal sebesar 75,8 MPa dan defleksi sebesar 0,259 m (gambar 7 dan 8). 


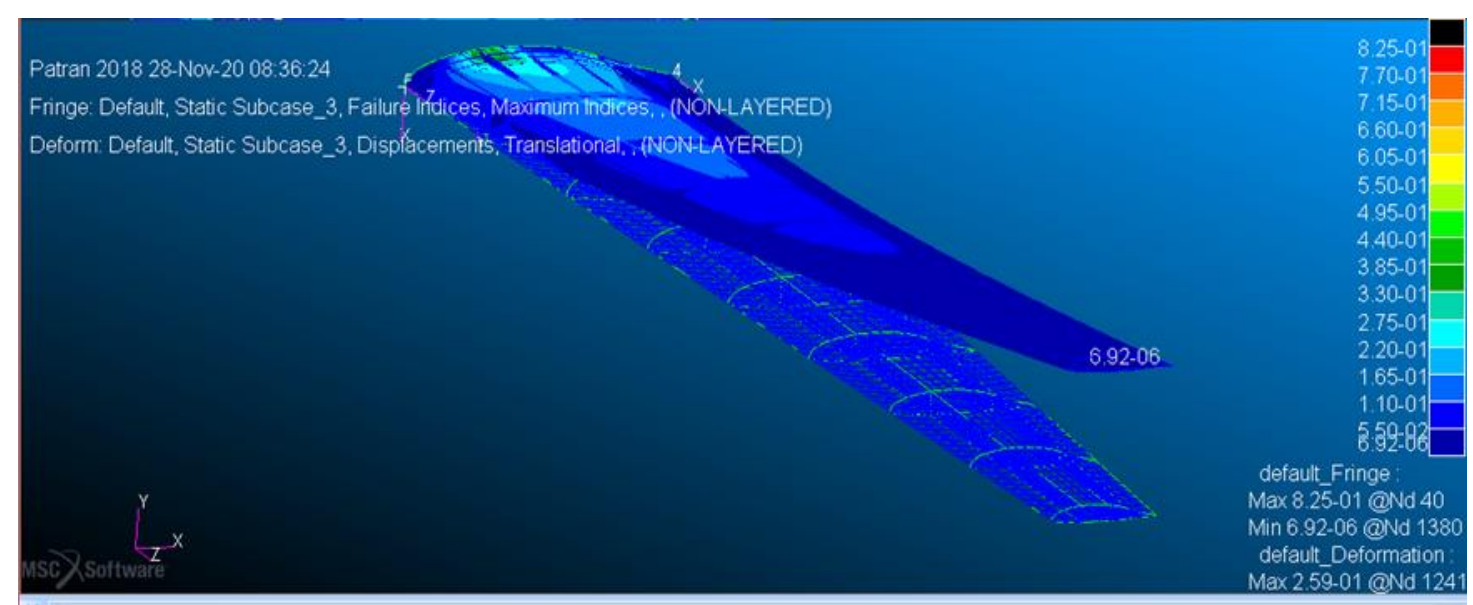

Gambar 7 Hasil Failure Indices dan deformasi komposit arah serat $90^{\circ}$

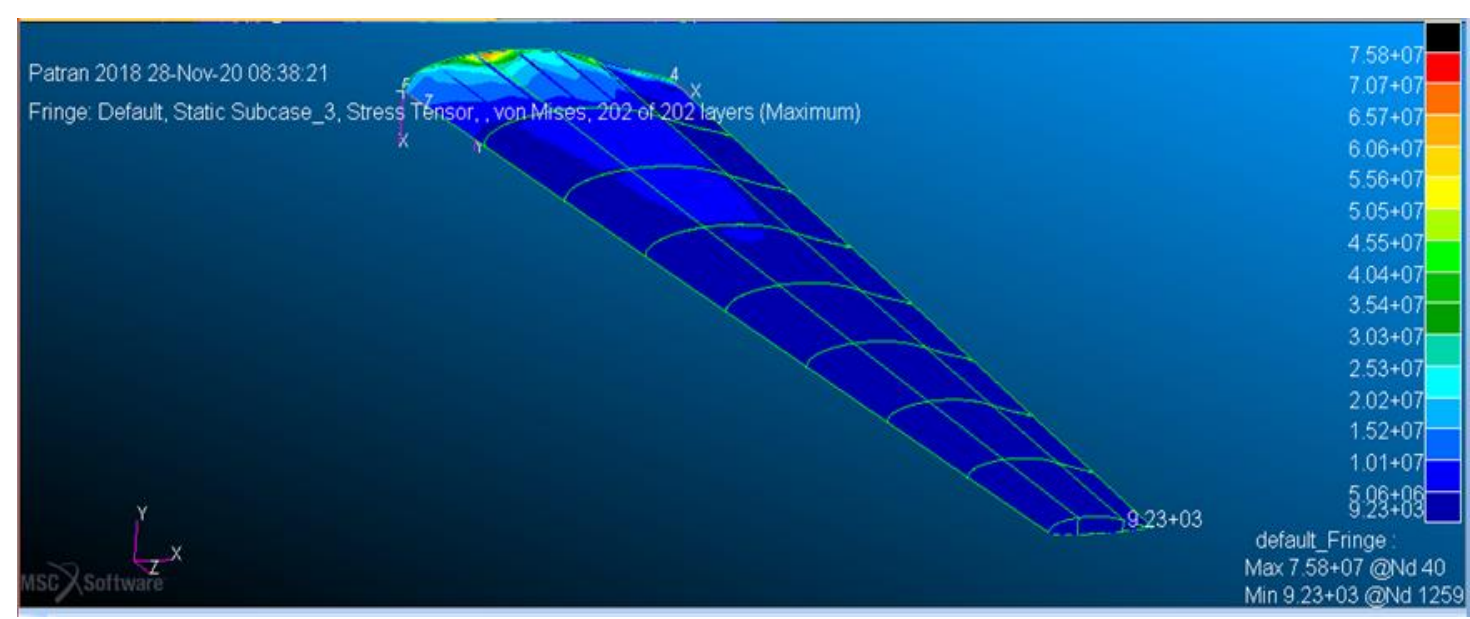

Gambar 8 Hasil stress material komposit arah serat $90^{\circ}$

Rancangan sayap komposit yang menggunakan arah fiber $\left(0^{\circ} / 0^{\circ} 90^{\circ} / 90^{\circ}\right)$ mampu menahan stress maksimal sebesar 86,1 MPa dan defleksi sebesar 0,0447 m (gambar 9 dan 10).

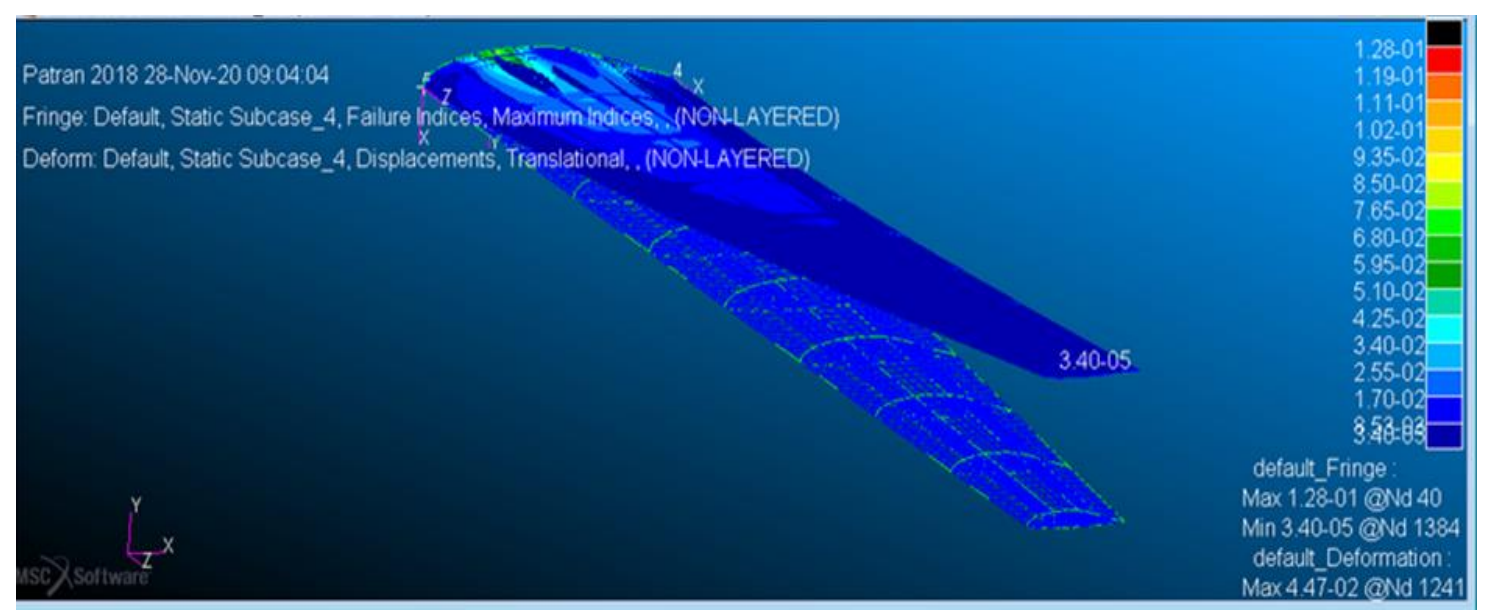

Gambar 9 Hasil Failure Indices dan Deformasi komposit arah serat $\left(0^{\circ} / 0^{\circ} 90^{\circ} / 90^{\circ}\right)$ 


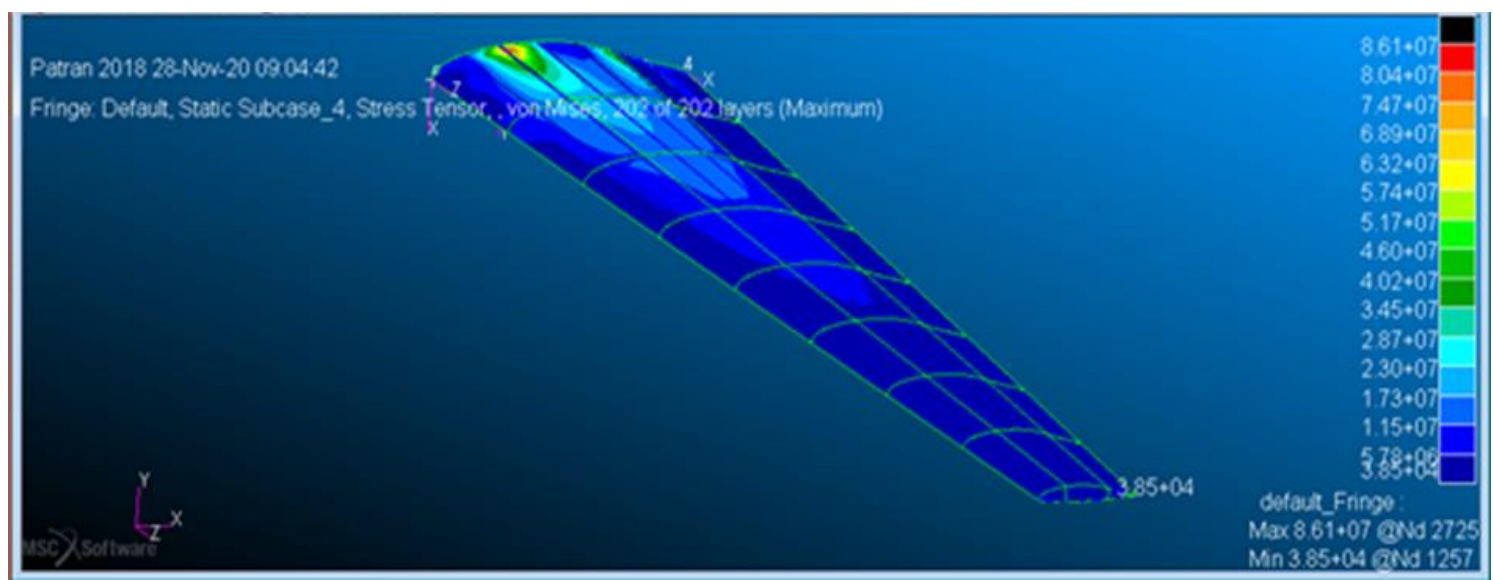

Gambar 10 Hasil stress komposit arah serat $\left(0^{\circ} / 0^{\circ} 90^{\circ} / 90^{\circ}\right)$

Rancangan sayap komposit yang menggunakan arah fiber $\left(0 \% / 45^{\circ} / 45^{\circ} / 90 \% / 90^{\circ}-45^{\circ} / 45^{\circ} / 0^{\circ}\right)$ mampu menahan stress maksimal sebesar 96,4 MPa dan defleksi sebesar 0,0446 m (gambar 11 dan 12).

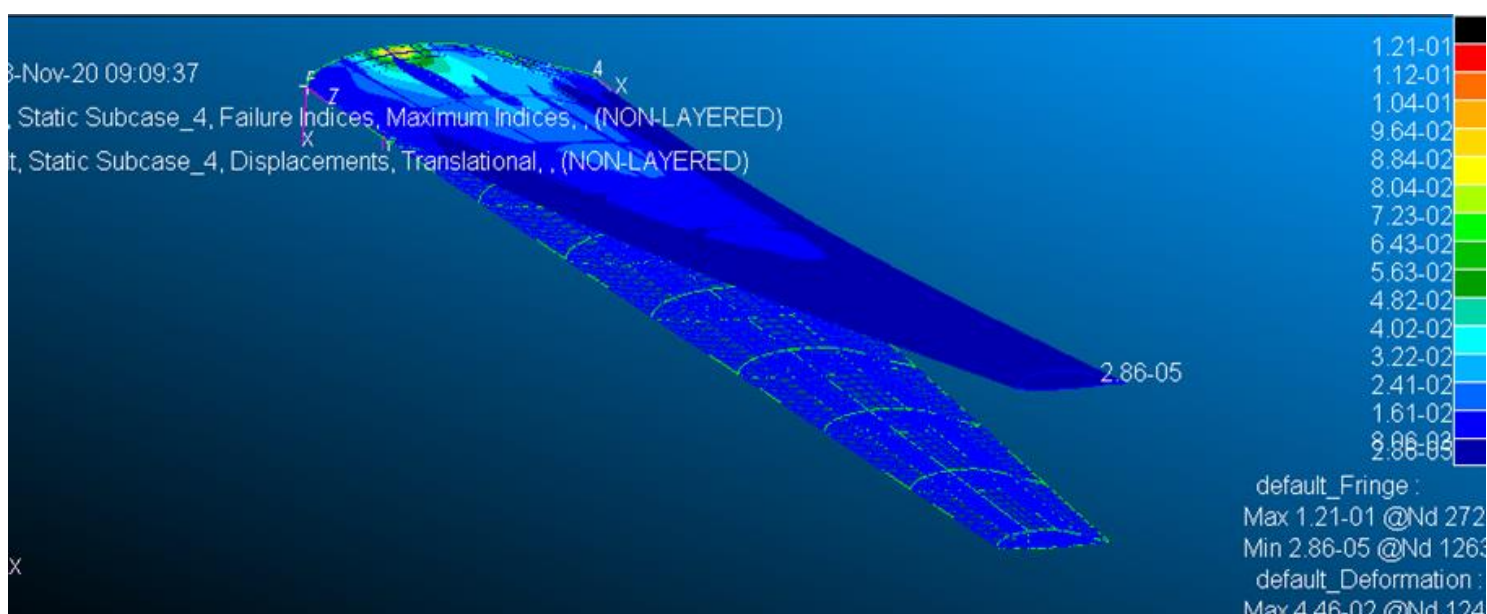

Gambar 11 Hasil Failure Indices dan deformasi komposit arah serat $\left(0^{\circ} / 45^{\circ} /-45^{\circ} / 90^{\circ}\right) \mathrm{s}$

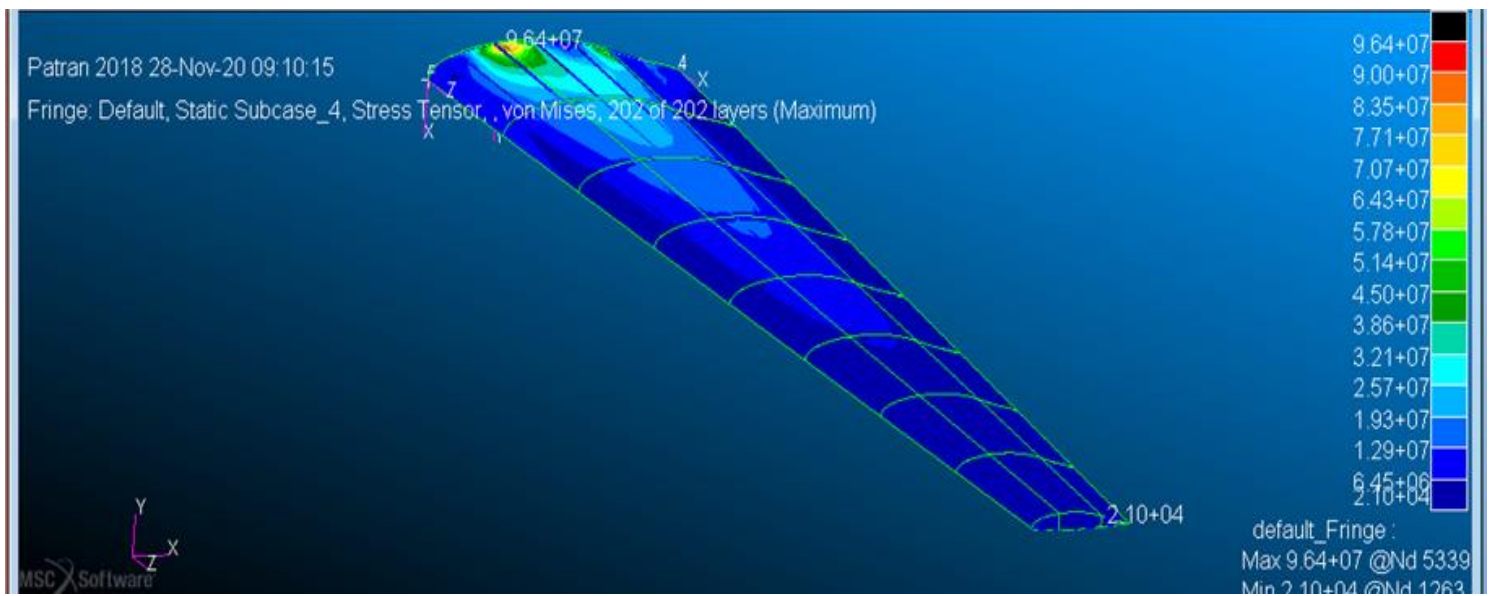

Gambar 12 Hasil Stress komposit $\left(0^{\circ} / 45^{\circ} /-45^{\circ} / 90^{\circ} / 90^{\circ} /-45^{\circ} / 45^{\circ} / 0^{\circ}\right)$

Rancangan sayap Alumunium AL-2024 T3 ketebalan 2,5 cm mampu menahan stress maksimal sebesar 59,2 Mpa (gambar 13 dan 14). 


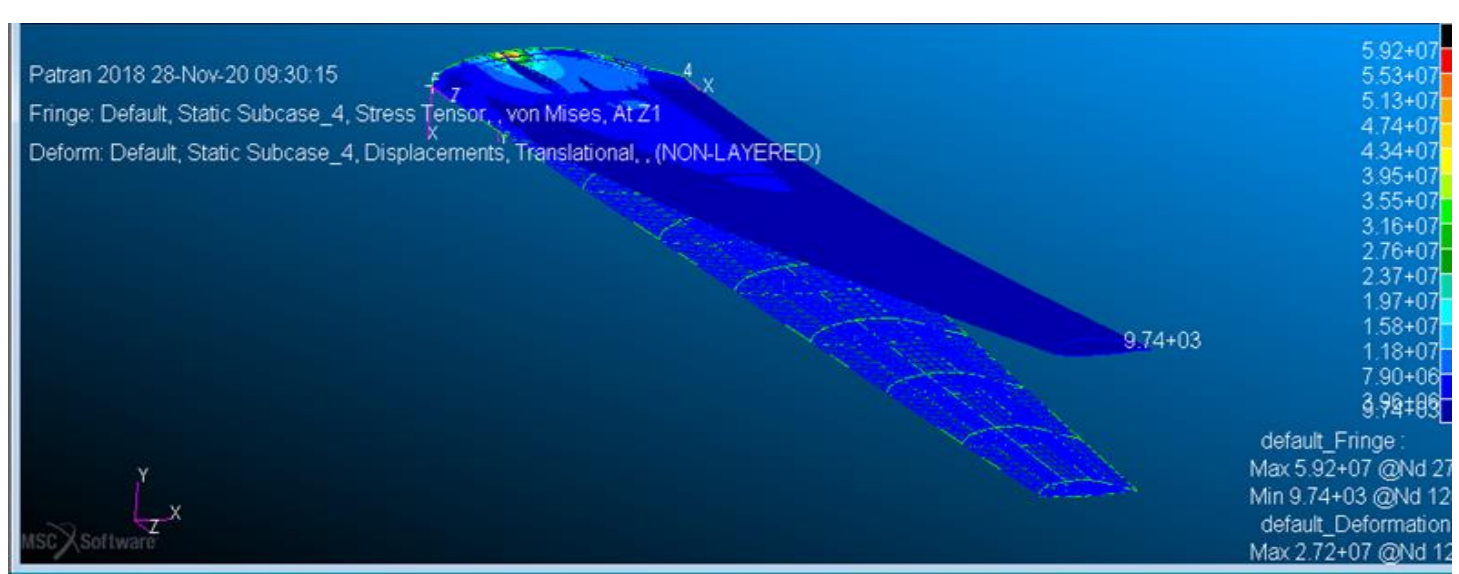

Gambar 13 Hasil stress Alumunium AL-2024 T3

Rancangan sayap Alumunium TI-6Al4 V ketebalan 2,5 cm mampu menahan stress maksimal sebesar 59,2 $\mathrm{MPa}$

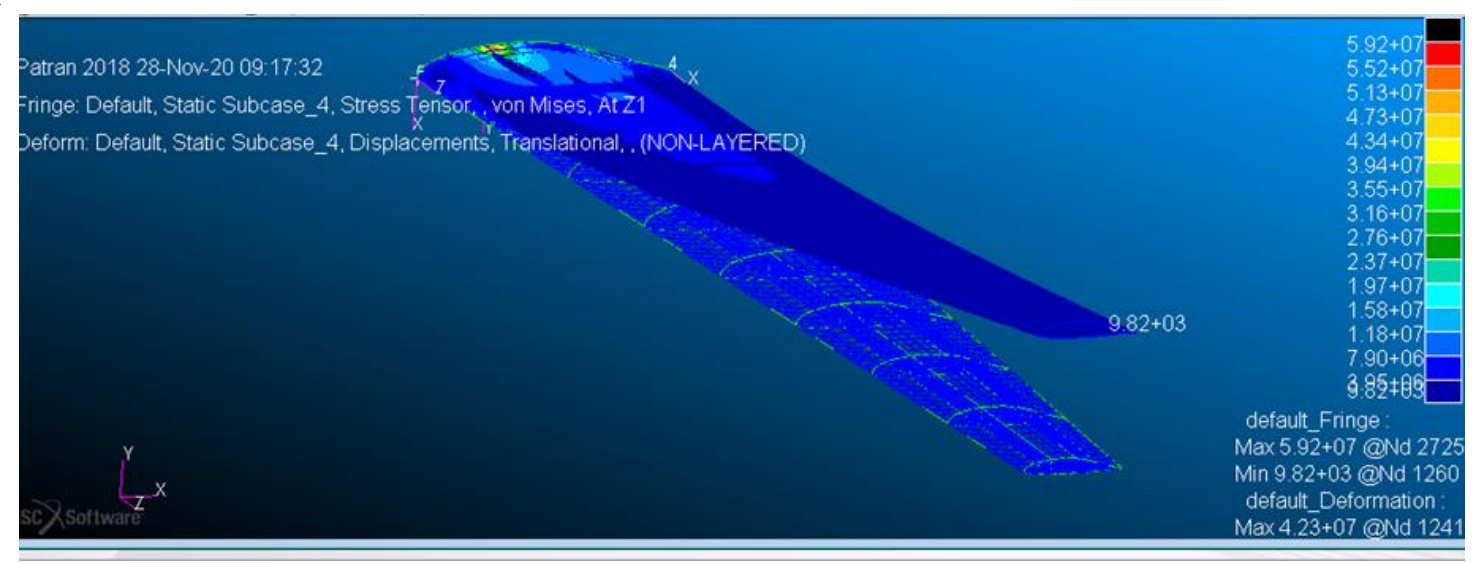

Gambar 14 Hasil Stress Titanium TI-6A14 V

Rancangan sayap komposit yang menggunakan arah fiber $\left(90^{\circ}\right)$ dengan thickness pada spar dan rib variasi $80(1 \mathrm{~cm}), 60(0,75 \mathrm{~cm})$ dan $40(0,5 \mathrm{~cm})$ layer serta $30(0,375 \mathrm{~cm}), 20(0,25 \mathrm{~cm})$ dan $10(0,125 \mathrm{~cm})$ layer pada skin, mampu menahan stress maksimal sebesar $551 \mathrm{MPa}$ dan defleksi sebesar 0,657 m (gambar 15 dan 16).

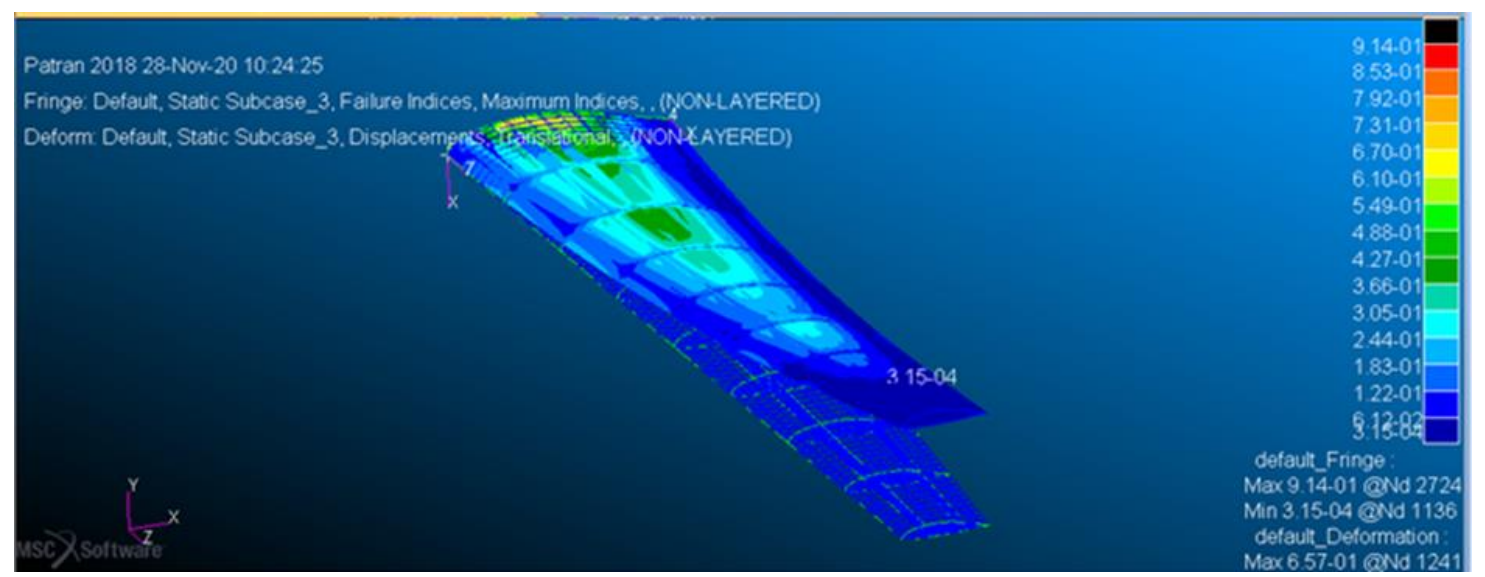

Gambar 15 Hasil FI dan deformasi Optimasi Desain Komposit 


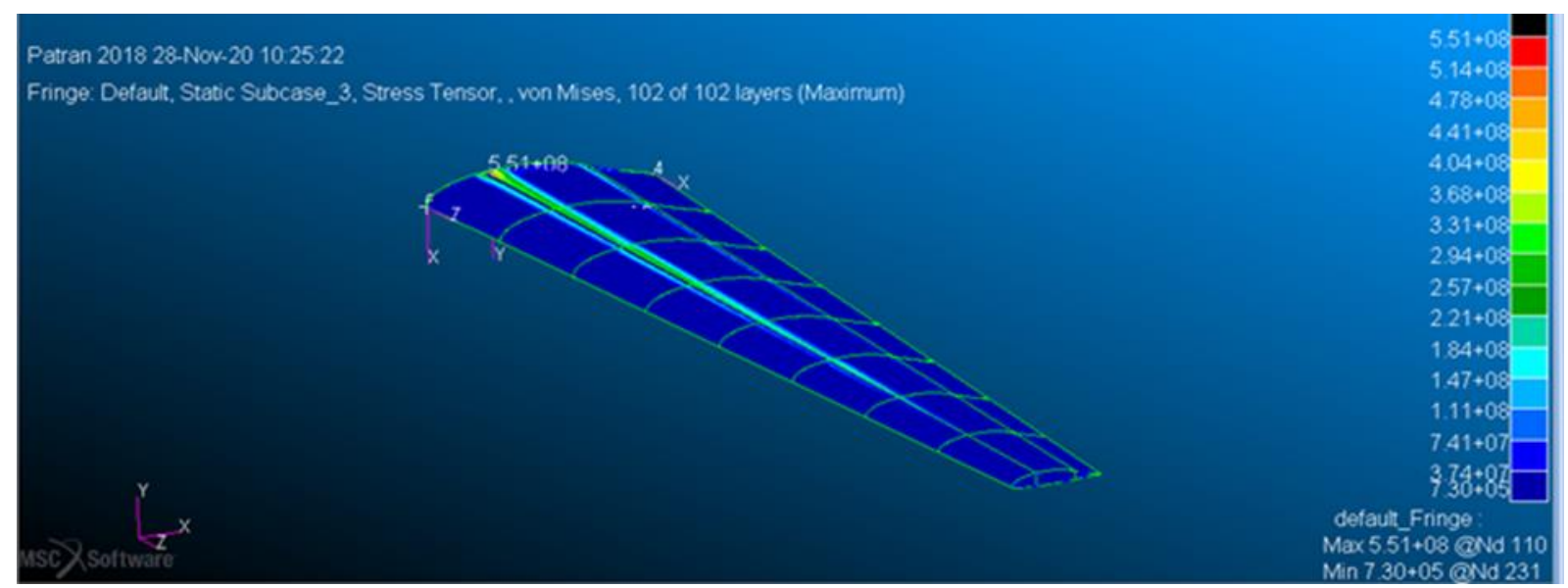

Gambar 16 Hasil stress Optimasi Desain Komposit

Untuk analisis sayap komposit ketebalan seragam data disajikan berurut dari stress, defleksi dan failure indices. Weight pada perbandingan ini tidak dicantumkan karena seluruhnya memiliki ketebalan yang seragam yaitu $2,5 \mathrm{~cm}$ atau $0,025 \mathrm{~m}$ (tabel 2 ).

Tabel 2 Perbandingan hasil data serat komposit ketebalan seragam

\begin{tabular}{ccccc}
\hline No & Arah serat Komposit & Stress & Defleksi & Failure Indices \\
\hline 1 & $\left(0^{\circ} / 0^{\circ} / 0^{\circ} / 0^{\circ}\right) \mathrm{s}$ & $97,8 \mathrm{MPa}$ & $0,0296 \mathrm{~m}$ & 0,0718 \\
\hline 2 & $\left(45^{\circ} / 45^{\circ} / 45^{\circ} / 45^{\circ}\right) \mathrm{s}$ & $99,6 \mathrm{MPa}$ & $0,152 \mathrm{~m}$ & 0,444 \\
\hline 3 & $\left(90^{\circ} / 90^{\circ} / 90^{\circ} / 90^{\circ}\right) \mathrm{s}$ & $75,8 \mathrm{MPa}$ & $0,259 \mathrm{~m}$ & 0,825 \\
\hline 4 & $\left(0^{\circ} / 0^{\circ} / 90^{\circ} / 90^{\circ}\right) \mathrm{s}$ & $86,1 \mathrm{MPa}$ & $0,0447 \mathrm{~m}$ & 0,128 \\
\hline 5 & $\left(0^{\circ} / 45^{\circ} / 45^{\circ} / 90^{\circ}\right) \mathrm{s}$ & $96,4 \mathrm{MPa}$ & $0,0446 \mathrm{~m}$ & 0,121 \\
\hline
\end{tabular}

Berdasarkan tabel diatas arah serat $\left(0^{\circ} / 0^{\circ} / 0^{\circ} / 0^{\circ}\right)$ s memiliki besar stress, defleksi dan weight yang terjadi pada sayap komposit dengan thickness yang seragam 0,025 $\mathrm{m}$ dan kondisi batas di spar untuk arah serat $\left(0^{\circ} / 0^{\circ} / 0^{\circ} / 0^{\circ}\right)$ s adalah sebesar $97,8 \mathrm{MPa}, 0,0296 \mathrm{~m}, 2,228 \times 10^{3} \mathrm{Kg}$. Failure Indices sebesar 0,0718, maka struktur tersebut dinyatakan aman. Untuk arah serat komposit $\left(45^{\circ} / 45^{\circ} / 45^{\circ} / 45^{\circ}\right)$ s memiliki besar stress, defleksi dan weight yang terjadi pada sayap komposit dengan thickness yang seragam 0,025 $\mathrm{m}$ dan kondisi batas di spar untuk arah serat $\left(45^{\circ} / 45^{\circ} / 45^{\circ} / 45^{\circ}\right)$ s adalah sebesar 99,6 $\mathrm{MPa}, 0,152 \mathrm{~m}, 2,228 \times 10^{3} \mathrm{Kg}$. Failure Indices sebesar 0,444, maka struktur tersebut dinyatakan aman.

Kemudian untuk arah serat $\left(90^{\circ} / 90^{\circ} / 90^{\circ} / 90^{\circ}\right)$ s besar stress, defleksi dan weight yang terjadi pada sayap komposit dengan thickness yang seragam $0,025 \mathrm{~m}$ dan kondisi batas di spar untuk arah serat $\left(90^{\circ} / 90^{\circ} / 90^{\circ} / 90^{\circ}\right) \mathrm{s}$ adalah sebesar $75,8 \mathrm{MPa}, 0,259 \mathrm{~m}, 2,228 \times 10^{3} \mathrm{Kg}$. Failure Indices sebesar 0,825, maka struktur tersebut dinyatakan aman. Lalu untuk arah serat bervariasi $\left(0^{\circ} / 0^{\circ} / 90^{\circ} / 90^{\circ}\right) \mathrm{s}$ besar stress, defleksi dan weight yang terjadi pada sayap komposit dengan thickness yang seragam 0,025 $\mathrm{m}$ dan kondisi batas di spar untuk arah serat $\left(0^{\circ} / 0^{\circ} / 90^{\circ} / 90^{\circ}\right)$ s adalah sebesar $86,1 \mathrm{Mpa}, 0,0447 \mathrm{~m}, 2,228 \times 10^{3} \mathrm{Kg}$ Failure Indices sebesar 0,128, maka struktur tersebut dinyatakan aman. Terakhir untuk arah serat $\left(0^{\circ} / 45^{\circ} / 45^{\circ} / 90^{\circ}\right) \mathrm{s}$ besar stress, defleksi dan weight yang terjadi pada sayap komposit dengan thickness yang seragam $0,025 \mathrm{~m}$ dan kondisi batas di spar untuk arah serat $\left(0^{\circ} / 45^{\circ} /-45^{\circ} / 90^{\circ}\right)$ s adalah sebesar 96,4 Mpa, 0,0446 m, 2,228 x $10^{3} \mathrm{Kg}$ Failure Indices sebesar 0,121, maka struktur tersebut dinyatakan aman. 
Tabel 3 Perbandingan hasil data serat komposit dengan Alumunium dan Titanium

\begin{tabular}{cccccc}
\hline No & Jenis Material & Thickness & Stress & $\begin{array}{c}\text { Failure Indices / } \\
\text { Margin of Safety }\end{array}$ & Weight \\
\hline 1 & Komposit T300 N5208 & $2,5 \mathrm{~cm}$ & $97,8 \mathrm{Mpa}$ & 0,0718 & $2228 \mathrm{Kg}$ \\
\hline 2 & Al 2024 T3 & $2,5 \mathrm{~cm}$ & $59,2 \mathrm{Mpa}$ & 3,56 & $3871 \mathrm{~kg}$ \\
\hline 3 & TI 6Al 4V & $2,5 \mathrm{~cm}$ & $59,2 \mathrm{Mpa}$ & 13,86 & $6168 \mathrm{~kg}$ \\
\hline
\end{tabular}

Dari data table diatas (tabel 3) tertera bahwa weight material komposit ketebalan seragam dari wingroot sampai wingtip 2,5 cm adalah $2228 \mathrm{Kg}$. Kemudian untuk Alumunium dan Titanium dengan ketebalan yang serupa memiliki weight sebesar $3871 \mathrm{Kg}$ dan $6168 \mathrm{Kg}$. Tentunya variable ini masih dapat di perkecil lagi dengan adanya optimasi desain sayap melalui variasi ketebalan sayap dan lain-lain. Tetapi dari sini dapat ditarik kesimpulan bahwa tanpa adanya variable yang lain, murni diukur dari weight material tersebut, komposit memiliki weight lebih ringan 42,4\% dari material Alumunium dan 63,8\% lebih ringan dari Titanium. Adapun Failure Indices yang dalam hal ini menggunakan Margin of Safety untuk material Alumunium dan Titanium menunjukkan angka 3,56 dan 13,86 yang berarti termasuk safe karena angkanya diatas 0 .

Optimasi desain sayap komposit dengan memberikan variasi ketebalan pada sayap dimana sayap dibagi kedalam 3 section dengan setiap section memiliki ketebalan yang berbeda dari wingroot ke wingtip, serta menambah jumlah kondisi batas. Hasil optimasi desain dituliskan sebagai berikut (tabel 4):

Tabel 4 Perbandingan hasil data Komposit hasil optimasi dan sebelum optimasi

\begin{tabular}{ccccccc}
\hline No & Struktur Sayap & Ketebalan & Stress & Defleksi & Failure Indices & Weight \\
\hline 1 & Sebelum Optimasi & Seragam & $97,8 \mathrm{MPa}$ & $0,029 \mathrm{~m}$ & 0,0718 & $2228 \mathrm{Kg}$ \\
\hline 2 & $\begin{array}{l}\text { Optimasi Pertama } \\
100 / 75 / 50 \text { layer }\end{array}$ & Variasi & $158 \mathrm{MPa}$ & $0,110 \mathrm{~m}$ & 0,534 & $311 \mathrm{Kg}$ \\
\hline 3 & $\begin{array}{l}\text { Optimasi Kedua } \\
\text { 80/60/40 layer }\end{array}$ & Variasi & $551 \mathrm{MPa}$ & $0,657 \mathrm{~m}$ & 0,914 & $277 \mathrm{Kg}$ \\
\hline
\end{tabular}

\section{Kesimpulan}

Semua struktur sayap (Ribs, Spar dan Skin) yang sudah dirancang menghasilkan struktur yang aman dengan indikator Failure Indices dibawah 1 untuk material komposit dan Margin of Safety lebih besar dari 0 untuk material Alumunium dan Titanium. Struktur sayap dengan arah serat $\left(0^{\circ} / 0^{\circ} / 0^{\circ} / 0^{\circ}\right)$ s dimana arah serat tersebut searah dengan Span Sayap menghasilkan Failure Indices dan Defleksi paling kecil dibanding dengan arah serat lainnya yang diuji dalam penelitian ini, ini artinya komposisi arah serat $\left(0^{\circ} / 0^{\circ} / 0^{\circ}\right)$ s ini merupakan komposisi arah serat paling efesien untuk menerima beban statik yang disimulasikan dalam penelitian ini. Weight sayap yang dirancang dengan ketebalan yang sama $0,025 \mathrm{~m}$ antara material komposit, alumunium dan titanium menghasilkan berat paling minimum pada material komposit. Weight yang dihasilkan dari Sayap komposit pada arah serat $\left(0 \% / 45^{\circ}-45^{\circ} / 90^{\circ}\right)$ s adalah $42,4 \%$ lebih ringan dari pada sayap alumunium dan $63,8 \%$ lebih ringan dari pada sayap Titanium. Sayap komposit dengan thickness yang sudah dioptimasi ketebalan dan kondisi batasnya menghasilkan 87,56\% lebih ringan dibanding sayap komposit sebelum dilaksanakan optimasi.

\section{Daftar Pustaka}

[1] Ali Salh Sawadi, Apr - May 2017, Analysis Of Composite Material For Wing Of Aircraft, International Journal of Mechanical Engineering (IJME) ISSN (P): 2319-2240; ISSN (E): 23192259 Vol. 6, Issue 3; $19-26$.

[2] Joyel K Joseph, Avinash Babu, 2015, Design, Modal and Stress Analysis of Aircraft Composite Wing, International Journal of Engineering Research \& Technology (IJERT) ISSN: 2278-0181 Published by, www.ijert.org ICESMARTConference Proceedings. 
[3] Yu-shan Meng, Li Yan, Wei Huang, Structural design and analysis of a composite wing with high aspect ratio, 8 Th European Conference For Aeronautics And Space Sciences (Eucass) DOI: 10.13009/EUCASS2019-95.

[4] Bambang K. Hadi, Muhammad A. Ghofur, IndraPermana, 2015 The Design of a High Aspect Ratio HALE Aircraft Composite Wing. Part I: Static Strength Analysis. Journal Of Mechanical Engineering An International Journal. Vol. 12(2), page no.1.

[5] M. Rajadurai, P. Vinayagam, G. Mohana Priya, K. Balakrishnan, 2017, Optimization of Ply Orientation of Different Composite Materials for Aircraft Wing, International Journal of Advanced Engineering Research and Science (IJAERS), [Vol-4, Issue-6, Jun- 2017] ISSN: 2349-6495(P) | 2456-1908(O).

[6] Michael C. Y. Niu, 2000 Composite Airframe Structure, Hongkong Conmilit Press LTD.

[7] Sofyan, B. T. 2010. Pengantar Material Teknik. Jakarta: Salemba Teknika.

[8] Muhammad, M., \& Yani, I. 2018. Analisis Kelenturan Struktur Sayap Pesawat UAV Terhadap Gaya Tekan Menggunakan Autodesk Inventor (Doctoral dissertation, Sriwijaya University).

[9] Ikhwansyah, Isranuri. 2016. Analisa Pengaruh Variasi Komposisi terhadap Kekuatan Tarik Statik dan Impak Komposit Berpenguat Serat Rockwool pada Pesawat Tanpa Awak

[10] Handoko, B., \& Bakar, A. 2020. Analisis Optimasi Tebal Rib Sayap Pesawat Wig In Ground Effect 2 Seat Dengan Fem. Jurnal Industri Elektro dan Penerbangan.

[11] Hanif, F., \& Yani, I. 2018. Analisis Tumbukan Pada Sayap Pesawat Tanpa Awak Jenis Sayap Tetap (Doctoral dissertation, Sriwijaya University).

[12] Indra Mawardi, Hasrin Lubis., Proses Manufaktur Plastik dan Komposit. Penerbit Andi, 2019 